\title{
A Ilha de Moçambique revisitada pela pena da poesia e pela tinta dos afetos*
}

\author{
Carmen Lucia Tindó Ribeiro Secco**
}

\begin{abstract}
RESUMO
A reescrita de Moçambique com a pena da poesia e as tintas dos afetos. Paisagens: poesia, pintura e história. O entrecruzamento de povos, culturas e saberes no chão moçambicano de heranças múltiplas.

Palavras-chave: Moçambique. Poesia. Pintura. História e afetos
\end{abstract}

Escrever um poema ou pintar um quadro é buscar o outro lado de uma presença: um e outro tentam, pela experiência, levantar a ponta de um véu, mostrar aos homens um lado ignorado ou antes esquecido do mundo que habitam. (NOVAES, 1994, p. 9).

Optamos, neste ensaio, por interpretar aguarelas do pintor Gemuce e composições poéticas do livro Mesmos barcos ou poemas de revisitação do corpo, (2007) de Sangare Okapi, poeta pertencente a uma das gerações poéticas moçambicanas mais recentes. A escolha de Gemuce e Okapi se deve ao fato de ambos focalizarem, em especial, a Ilha de Moçambique, espaço prenhe de significações, na medida em que foi cenário de importantes episódios históricos e trocas culturais, tendo sido, também, ao longo dos anos, uma metáfora recorrente no imaginário das artes moçambicanas. Nossa intenção é investigar de que modo tanto a poesia, como a pintura participam da história, desvelando sentidos, afetos e saberes que se encontravam ocultos ou olvidados.

Ilha, espaço de sedução e encantamento - imagem constante na memória de poetas e pintores moçambicanos. Ilha, lugar de reencontro com as origens, do repensar da poesia, da pintura, das paisagens, dos afetos.

Antes de passarmos aos poemas de Sangare Okapi e às aguarelas de Gemuce, fazem-se necessárias algumas informações sobre a Ilha de Moçambique,

* UFRJ e CNPq. Este texto resulta de projeto desenvolvido na UFRJ, com financiamento do CNPq, que gerou, também, o artigo "Revisitações Poéticas e Pictóricas da Ilha de Moçambique", publicado na Revista Eletrônica Abril. Revista do NEPA/UFF. Vol. 5, No 9. Niterói, novembro de 2012, pp. 205217. ISSN: $1985-2090$

** Universidade Federal do Rio de Janeiro - UFRJ 
considerada patrimônio da humanidade pela UNESCO e local de entrecruzamentos étnicos, históricos, culturais que deram origem a Moçambique.

No litoral norte moçambicano, as ilhas, em grande parte, eram despovoadas. As etnias africanas de origem banto habitavam o continente. Em meados do século VII, os árabes islamizaram a costa oriental da África. Quando os portugueses aportaram, no final do século XV, na Ilha de Moçambique - chamada Muipíti pelos povos africanos macuas que habitavam o local -, encontraram ali um xecado árabe. Empreenderam, então, a conquista, tentando impor seu poder. Textos de cronistas e poetas relatam como os portugueses, ao ocuparem a Ilha de Moçambique, ergueram fortalezas e igrejas, buscando sobrepor sua cultura à dos mouros:

A povoação portuguesa organizou-se, no século XVI, à volta da Torre Velha, situando-se a dos árabes ou mouros no sítio do Celeiro. $\mathrm{O}$ fosso religioso que na época separava os homens obrigava-os a terem bairros diferentes, cada qual com seus templos privativos. (LOBATO, 1992, p. 171).

O domínio português difundiu seus estereótipos e seus fetiches, tratando como "outros" não só os negros de origem banto, mas também os indianos, os árabes e os "mouros negros" da região, passando aos colonizados seus preconceitos contra os africanos e os orientais .

Segundo Edward Said, em seu livro Orientalismo, a relação entre o Ocidente e o Oriente foi edificada em torno de questões de poder; e, para que este fosse alcançado, o Ocidente sempre representou negativamente os árabes e indianos, caracterizando-os como povos nômades, exóticos, desonestos, ladrões, traficantes de escravos, ouro e marfim. Desse modo, a imagem do "Oriente foi, quase sempre, tecida como uma invenção do Ocidente" (SAID, 1990, p. 13) para justificar a hegemonia deste último.

Com essa caracterização discriminatória, a colonização lusitana procurou silenciar os traços orientais da cultura moçambicana, fazendo com que esta se esquecesse de que "não foi pela mão dos portugueses que a pequena Ilha de Moçambique entrou na História, mas pela dos árabes, que nela se instalaram ao longo da costa oriental da África" (LOBATO, A., ${ }^{1992, ~ p .169)}$, bem antes da chegada, em 1498, de Vasco da Gama.

A responsabilidade pelo fato de a história mais remota da Ilha de Moçambique ser mal conhecida deve-se, pelo menos em parte, aos próprios portugueses, cuja política de ocupação da ilha conduziu à dispersão e ao desaparecimento das comunidades muçulmanas que 
ali habitavam durante a era pré-gâmica. Com isso, se esgarçaram as lendas fundadoras e as tradições que narravam a história do xecado e do sultanato ali existentes. (LOBATO, M., 1996, p. 11).

Não conseguindo extirpar totalmente os cultos e costumes árabes, a política lusitana foi a de segregá-los, impingindo uma visão preconceituosa a respeito deles, principalmente a partir da segunda metade do século XIX, época em que se desenvolveu intensa e sistemática colonização portuguesa em África, pois, até então, Portugal estivera ocupado com o comércio do ouro, do marfim e com o tráfico negreiro para o Brasil. A Ilha de Moçambique fez parte da rota da escravidão, funcionando como depósito dos escravos que eram vendidos para as Américas. Com o fim do tráfico, a Ilha entrou em decadência, mas os povos que por lá passaram deixaram suas marcas culturais presentes em costumes e cultos que continuaram a ser praticados.

Durante a ocupação portuguesa, as ilhas se tornaram pontos estratégicos de defesa do continente; foram também locais de exílio e prisões. Mais tarde, com as lutas pela independência e, posteriormente, com a guerra civil, cujas batalhas foram travadas, na maioria das vezes, no interior das terras continentais de Moçambique, alguns desses espaços insulares foram usados como lugares de detenção e tortura; outros serviram de refúgio aos deslocados de guerra.

Esquecidas durante anos, algumas dessas ilhas guardaram, entretanto, em suas entranhas, muitas das tradições; tornaram-se, desse modo, metafóricos reservatórios de vestígios culturais que resistiram ao tempo e à opressão.

No fim dos anos 80 e início dos 90 do século XX, com o enfraquecimento das utopias revolucionárias, alguns poetas e escritores, ao verem o território moçambicano aviltado pelos longos períodos de guerra, buscaram espaços menos atingidos por esta. Voltaram-se, então, para o imaginário do mar e das ilhas, à procura de Eros, do amor e das origens. Essa é uma das tendências da poesia dessa época, constatada em poemas de Luís Carlos Patraquim, Mia Couto, Eduardo White, Armando Artur, entre outros.

A Ilha de Moçambique, contudo, não foi apenas celebrada por esses poetas da pós-independência. Foi cantada, também, por vozes poéticas anteriores, dentre as quais: as de Campos de Oliveira, Rui Knopfli, Orlando Mendes, Glória de Sant'Anna, Virgílio de Lemos, os dois últimos conhecidos como os poetas do mar do norte de Moçambique.

Ana Mafalda Leite, em estudo sobre a poesia moçambicana atual, apresentado em aulas ministradas na Pós-graduação de Letras Vernáculas da UFRJ em 2010, chama atenção para o diálogo que determinadas poéticas de jovens autores 
efetuam com as de representantes do lirismo anterior, formando como que um tecido palimpséstico:

o processo de mitificação literário da Ilha de Moçambique tem vindo a ser actualizado e amplificado, nos últimos anos, com maior insistência na obra de vários autores, concretizando percursos alternativos a uma poética militante e de cariz ideológico, conferindo uma outra amplitude aos imaginários poéticos, e actualizando uma "herança" e tradição literárias, muito antigas. (LEITE, 2003, p. 137).

Sangare Okapi é um desses novos poetas moçambicanos que reconhece o legado lírico do passado, assumindo-se como herdeiro desse patrimônio literário-cultural que atualiza e amplia em seus versos, tributários de uma "irreprimível geografia do afecto" (OKAPI, 2007, p. 44). Afeto, entendido não somente como emoção e sentimentos despertados por lugares, poemas, poetas, mas também como tudo que abala o ser.

Com base na teoria dos afetos de Spinoza, Muniz Sodré chama atenção para o fato de que, no domínio da imaginação criadora, existe uma "potência emancipatória", que impede as artes de capitularem ao peso esmagador da razão. Resenha acerca desse livro de Muniz Sodré, publicada no jornal O Globo, de 1908-2006, acentua que, de acordo com o pensamento spinoziano, no literário e no artístico, em geral, delineia-se

\begin{abstract}
um movimento de aproximação das diferenças; uma estratégia, cujo momento decisivo se dá no sensível, na "zona obscura e contingente dos afetos", no primado não da razão instrumental e dos seus mecanismos de poder, mas sim da estética enquanto estesia, isto é, afeto, "emoção lúcida", sentimento como "afecção deliberada, consciente, refletida, lúcida e serena". (PECORARO, 2006, p. 5 destaques nossos).
\end{abstract}

A poesia é, assim, concebida como "potência de afetos", como alarme, assombro, aquilo que fascina, arrebata, e, por isso, se revela prenhe de erotismo. Este, tomado no sentido que lhe confere Georges Bataille, ou seja, como uma pulsão interior que coloca o ser em questão, fazendo-o refletir sobre a vida, a existência, a poesia.

Na poética de Sangare Okapi, está presente o assombro de um lado, e, de outro, um forte sentimento de angústia. Assombro, como expressão do fascínio frente à própria criação poética e ao passado literário moçambicano; angústia, como lúcida afecção diante das contradições do presente, cujo vazio faz o poeta declarar: "há um pequeno país/ no meu país:/ chama-se angústia". (OKAPI, 2007, 
p. 44) E são esses sentimentos de inquietação e estranheza que fazem desencadear a viagem uterina que o sujeito poético empreende pelo ventre do Índico e da Ilha, metonímias de Moçambique. É uma viagem erótica e intertextual pelos meandros da literatura, à procura de uma identidade literária. O poema se faz "abstrato barco" (OKAPI, 2007, p. 13) e a travessia náutica se inicia, por entre náusea e melancolia, rumo ao litoral norte, onde se encontram as matrizes culturais de Moçambique. Confessando-se "nu e vazio" (OKAPI, 2007, p. 15), o poeta penetra no "túnel da memória" (OKAPI, 2007, p. 15) e se lança na vertiginosa "geografia do vento" (OKAPI, 2007, p. 13), metáfora de sua imaginação criadora que, em labiríntica busca, persegue uma dicção poética singular, em meio à monotonia da sufocante realidade ao redor.

Como um barco, sem porto, eriça a sensível vela do corpo e, frágil, o coração nos sirva de bússola:

os remos dispensa, temos as mãos para a navegação.

(OKAPI, 2007, p. 43).

Elegendo os sentimentos como bússola, o poeta se transforma em um lugar de afeto. Dá asas à emoção, deixando que uma poética do sensível se construa, à medida que navega. Sem porto, à deriva, segue em direção à insula matricial, cujo corpo, desejante e desejado como o da mulher amada, eriça a pele e a vela do barcopoema. Pela memória e pela linguagem, percorre o sistema literário moçambicano, recuperando os poetas do Índico.

A ilha de Moçambique nunca é nomeada, mas sim evocada através do jogo intertextual e de um conjunto de referências que remetem ao seu espaço. Pelos títulos dos poemas, se entrelaçam o roteiro (poético e privado) da Ilha de Próspero, de Knopfli, e a errância insular de Virgílio de Lemos. (...)

(FALCONI, 2011).

Mesmos barcos ou poemas de revisitação do corpo, de Sangare, apresenta três partes. A primeira, com mais poemas, celebra diversos poetas moçambicanos. A segunda, intitulada "Mesmos Barcos", com poemas, cuja forma se aproxima à da prosa, faz uma clara alusão a dois importantes poetas moçambicanos: Luís Carlos Patraquim e Eduardo White. A terceira, denominada "O Barco Encalhado", é formada por um único poema, cujo título coincide com o desta parte, constituindo uma homenagem a Campos Oliveira, o primeiro poeta de Moçambique. 
$\mathrm{Na}$ parte primeira, Okapi inicia a viagem que faz emergirem, do fundo da memória, vozes líricas do Índico e da Ilha de Moçambique, a "Ilha Dourada", de Rui Knopfli, autor de A Ilha de Próspero. O poema "Mossuril", de Sangare, dedicado a Knopfli, traz imagens do mar e da lágrima, metaforizando a solidão dessa mítica ilha, cuja magia inspirou tantos poetas. "Língua: ilha ou corpo?", poema ofertado a Virgílio de Lemos, faz referências a esse poeta, cuja obra poética sempre refletiu sobre o corpo e o erotismo da linguagem.
A V.L.
A língua
é o pão que fermento
os dias todos.
Com ela (re)invento, meço outros ângulos do sentimento.
(...)
Eis o que sou: ilha
ou corpo cercado
de gente
por todos os lados.

(OKAPI, 2007, p. 20)

Muitos são os poetas lembrados: Heliodoro Baptista, Guita Jr., Gulamo Khan, Eugénio Lisboa etc. No poema "Patraquimmiana", Sangare rende homenagem a dois grandes poetas de Moçambique: Patraquim e José Craveirinha:

Para J. C.

Não sei com que estranha miragem. Confesso.

Meu lírico cartomante das noitadas pela Mafalala!

Sim, agora que o medo já não puxa lustro na cidade. Velho Zé, Livre e limpo da morte, regressas pelos carris da memória, mãos aninhadas nos bolsos rotos.

(...)

E regressas, velho Zé, poeta em todas as latitudes!...

(OKAPI, 2007, p. 39).

A travessia da memória empreendida por Okapi revisita a tradição lírica moçambicana, exaltando a importância de Craveirinha. Por intermédio de jogos intertextuais, traz versos famosos desse grande poeta que foi condecorado com o 
Prêmio Camões em 1991.

Descrevendo paisagens da Ilha de Moçambique - a baía, a fortaleza, os pangaios, os riquexós, o mar, as mulheres com o $m$ 'siro -, os poemas de Okapi vão traçando uma cartografia insular, que, subjetivamente, vai sendo erotizada e se torna alvo de uma relação amorosa: Ilha, corpo, mulher; Ilha, pátria, poesia.

Hoje, quase que instintiva e furtivamente, revisito-te. Exposta silhueta de mulher, na textura índica, esperando o tempo. Em Mossuril, preso o marisco na rede. Posso, agora, sem receio algum, vociferar no poema: amo-te! Amo-te as curvas, não sei que perigo ou mistério, a serena música das dunas no peito, romaria em alguma boca explodindo, ou então, a alga na bexiga se multiplicando. Olha a água, agora à nossa volta! A vertigem!?! Em ti, barco sem destino, nu me acoito inteiro e, se remar-te é engano, provável é agora rimarmo-nos. (OKAPI, 2007, p. 45)

Nesse poema, é clara a intertextualidade com Patraquim e Eduardo White, em cujos versos a Ilha de Moçambique, antropomorfizada, é decantada como erótica mulher de heranças culturais múltiplas.

Ilha, corpo, mulher. Ilha, encantamento. Primeiro tema para cantar. Primeira aproximação para ver-te, na carne cansada da fortaleza ida, na rugosidade hirta do casario decrépito, a pensar memórias, escravos, coral e açafrão. Minha ilha/vulva de fogo e pedra no Índico esquecida. (PATRAQUIM,1991, pp. 41-42).

Sou ao Norte a minha Ilha, os sinais e as sedas que ali se trocaram e nessa beleza busco-te e para mim algum percurso, alguma linguagem submarina e pulsional, busco-te por entre as negras enroladas em suas capulanas arrepiadas, altas, magras, frágeis e belas como as missangas (...)

Amo-te sem recusas e o meu amor é esta fortaleza, esta Ilha encantada, estas memórias sobre as paredes e ninguém sabe deste pangaio que a Norte e na Ilha traz um amante inconfortado. Em tudo habita ainda a tua imagem, o m'shiro purificado da tua beleza e das tuas sedes, (...) (WHITE, 1997, pp. 24-27).

Ilha de contrabandos e saberes, decorrentes da hibridação de povos e culturas. Nos cenários descritos nos poemas, faz-se visível essa diversidade cultural. Convivem fortalezas, ícones da arquitetura colonial portuguesa, com pangaios, pequenas embarcações de origem asiática; com riquexós, carruagens puxadas 
por homens, originárias da Ásia - China (Macau), Japão, Índia -; com o m'siro, cosmético feito de raiz típica, usado pelas mulheres africanas da Ilha, da etnia macua, para amaciarem a pele de seus rostos. Igrejas católicas, mesquitas árabes, templos hindus coexistem no espaço da Ilha, revelando a presença de religiosidades diversas.

Na última parte do livro de Sangare, o poema "O Barco Encalhado" faz homenagem a Campos de Oliveira, poeta oitocentista que primeiro cantou a Ilha. O eu-lírico refere povos que, no decorrer dos séculos, viveram na Ilha de Moçambique, fazendo desta um local culturalmente hibridizado. Termina com uma forte crítica à exploração predadora dos portugueses:

\author{
(...) Resgatasse o Índico o que do oriente com o tempo soube \\ sufragar. \\ Os barcos todos com as velas hirtas e as gentes. \\ Suas as pérolas mais os rubis. O aljôfar. Luzindo no ar. \\ Minha fracturada chávena árabe persa na cal \\ ou resplandecente a missanga cravada no ventre d'água, \\ qual sinal dos que de além mar chegaram \\ e partiram com baús fartos... \\ Fobia dos que ficamos. Mas herdeiros. \\ (OKAPI, 2007, p. 49).
}

A poética de Sangare Okapi se organiza a partir de três semas recorrentes: viagem, paisagens e memória. Seus poemas efetuam uma viagem anti-épica e intertextual pelas entranhas da história e da poesia moçambicanas. Cruzam imagens e paisagens com afetos que despertam a memória do passado.

Segundo Michel Collot, a paisagem é subjetiva, pois depende de quem a olha e de onde é olhada. Toda paisagem implica um horizonte, um olhar, uma perspectiva. No caso dos poemas do livro Mesmos barcos, de Sangare, o olhar do eu-lírico é pós-colonial, pois, conforme Ana Mafalda Leite, "faz uma desconstrução do mar imperial dos conquistadores, substituindo-o por um mar feminino". (LEITE, 2010, aula UFRJ), que cerca a Ilha de Moçambique. Há uma fascinação pelas ruínas do tempo; contudo, os fortes, as igrejas, as construções da Ilha não são exaltados por seus traços coloniais, mas pela beleza da arquitetura enquanto arte. A lírica de Okapi é voltada contra a destruição e o abandono sofridos pela Ilha. O mesmo ocorre com as aguarelas do pintor Hilário Gemuce, designado "o pintor da Ilha".

Aguarelas são muito usadas em representações de paisagens. Técnica empregada desde a Idade Média, em papéis tipo pergaminho, suas principais características são a transparência e a fluidez que fazem com que as cores possam ser exploradas em todos os seus tons. Por serem transparentes, deixam ver fragmentos de outras 
imagens, como se fossem palimpsestos. As tintas, desmanchadas com água, tornam as imagens diluídas. Assim, esse tipo de pintura, por meio de pinceladas esbatidas, de figuras desbotadas que dão a impressão dos anos e séculos decorridos, se presta à revisitação do passado.

$\mathrm{O}$ aquarelismo é uma pintura livre, que prima pela espontaneidade; relacionase à luz, à profundidade, a cenários e paisagens que são apreendidos com a emoção do olhar e do sentir. Por isso, é bastante empregado para retratar memórias e ruínas, captando centelhas de cenas perdidas do outrora longínquo.

Gemuce, em suas aguarelas, efetua uma iconografia da Ilha, ou seja, uma pictografia insular. Apreende paisagens naturais e humanas: o mar; as embarcações - barcos tradicionais e pangaios (cf. TELA 1) -; mulheres macuas, carregando latas d'água (cf. TELA 2); igrejas; fortalezas; palácios (cf. TELA 3); mesquitas; templos hindus; crianças jogando futebol (cf. TELA 4) ; o pânico provocado pela passagem d'El Niño; um barco abandonado na areia. Este, imagem frequente na Ilha, pode ser visto como significativa metáfora da história moçambicana que precisa ser revista por um olhar descolonizador, ou seja, por um olhar liberto de uma visão colonial. É sintomático que também Sangare Okapi tenha um poema com o mesmo título desta tela de Gemuce: "O Barco Encalhado" (cf. TELA 5). Tanto no texto de Sangare, como nessa aguarela, o barco está voltado para a praia, para a Ilha, metaforizando a viagem pelas entranhas insulares, num processo de ressignificação aprofundada da história e da geografia local.

No processo de representação simbólica, as aguarelas de Gemuce manifestam uma densidade que remete a vários tempos, colocando em confronto o presente de solidão e desamparo da Ilha com um passado de luxo e poder, de que são testemunhos os palácios, os fortes, as estátuas, em ruínas. Articular tais relações é buscar compreender a dor da pintura, interpretando sua emoção e seus fantasmas, sua densidade pictórica que teatraliza fragmentos da história dessa Ilha. O pincel de Gemuce expressa cenas do presente, do cotidiano insular que contrastam com a história de dominação depreendida da arquitetura colonial. Imagens líricas da Ilha se chocam com a memória da colonização e é, justamente, esse embate que afeta os espectadores, levando-os a perceber e a repensar "o contrabando de culturas e saberes" que, ali, ocorreu ao longo dos séculos. Os traços diluídos das imagens das aguarelas permitem a compreensão do descaso para com a Ilha, o entendimento da dimensão do isolamento dos seres humanos que vivem nesse espaço. Não existe uma narrativa nas telas, mas uma descrição que efetua uma poética dos vazios existentes nessa insula matricial. É assim que as pinturas de Gemuce deixam de ser meros registros objetivos da Ilha, tornando-se uma percepção sensível e 
subjetiva das paisagens insulares.

De acordo com Michel Collot, as paisagens "são ligadas a pontos de vista subjetivos, servindo como espelhos da alma. (...) A busca de um horizonte privilegiado implica, portanto, a busca de si mesmo. Assim, buscar uma paisagem é procurar a própria identidade" (COLLOT, 2010, p. 207).

Concluindo, observamos que tanto os poemas de Sangare, como as aguarelas de Gemuce se plasmam como exercícios de não esquecer, como lugares de compartilhamento da emoção e de enfrentamento da memória colonial. Ambos, em suas artes, captam a subjetividade das paisagens da Ilha de Moçambique como forma de reencontrarem suas moçambicanas matrizes identitárias. Sangare Okapi retoma, literária e metapoeticamente, o tema do Índico e a inspiração insular, ressignificando, a partir dos afetos, a tradição lírica moçambicana, com uma poesia que apresenta um olhar anti-épico e descolonizador. Gemuce, em suas aguarelas, representa, liricamente, paisagens da Ilha, captadas por sentimentos despertados pelos lugares que desencadeiam lembranças individuais e coletivas, fazendo emergir uma história subjetiva que põe em suspeita visões hegemônicas e imperiais da história.

\begin{abstract}
The rewriting of Mozambique with the pen of poetry and the ink of affections. Landscapes: poetry, painting and history. The intercrossing of people, cultures and different knowledges in the Mozambican ground of multiple inheritances.
\end{abstract}

Keywords: Mozambique. Poetry. Painting. History and affections

Referências

BENJAMIN, Walter. Magia e técnica, arte e política. Tradução de Sérgio Paulo Rouanet. 2. ed. São Paulo: Brasiliense, 1986.

COLLOT, Michel. Do Horizonte da Paisagem ao Horizonte dos Poetas. In: ALVES, Ida Ferreira e FEITOSA, Márcia Manir. Literatura e paisagem: perspectivas e diálogos. Tradução de Eva Nunes Chatel. Niterói: EdUFF, 2010.pp. 191-217. 
FALCONI, Jessica. Utopia e conflittualità. Ilha de Moçambique nella poesia mozambicana contemporanea. Roma: Aracne, 2008.

FALCONI, Jessica. As margens da nação na poesia de Sangare Okapi e Helder Faife. In: Revista Mulemba n. 4. Rio de Janeiro: Setor de Literaturas da UFRJ, julho de 2011. http://setorlitafrica.letras.ufrj.br/mulemba/artigo.php?art=artigo_4_5.php

LEITE, Ana Mafalda. Literaturas africanas e formulações pós-coloniais. Lisboa: Colibri, 2003. pp. 135-160.

LOBATO, Alexandre. A Ilha de Moçambique: notícia histórica. In: SAÚTE, Nelson e SOPA, António. A Ilha de Moçambique pela voz dos poetas. Lisboa: Edições 70, 1992, p.171.

LOBATO, Manuel. A Ilha de Moçambique antes de 1800. In: Oceanos. - no 25. Revista da Comissão Nacional para as Comemorações dos Descobrimentos Portugueses. Lisboa, jan.- março 1996, p. 11.

NOVAES, Adauto. Constelações. In: NOVAES, Adauto (Org.) Artepensamento. São Paulo: Companhia das Letras, 1994, p. 9.

OKAPI, Sangare. Mesmos barcos ou poemas de revisitação do corpo. Maputo: Associação dos Escritores Moçambicanos, 2007.

PATRAQUIM, Luís Carlos. Os barcos elementares. In: Vinte e tal novas formulações e uma elegia carnívora. Lisboa: ALAC, 1991. pp. 41-42.

PAZ, Octavio. A dupla chama: amor e erotismo. Tradução de Wladyr Dupont. São Paulo: Siciliano, 1994.

PECORARO, Rossano. Afetos que fundamentam o mundo contemporâneo. Jornal O Globo. Caderno Prosa e Verso. Rio de Janeiro, 19-08-2006. p. 5.

PRIGOGINE, Ilya. O fim das certezas: tempo, caos e as leis da natureza. Tradução de Roberto Leal Ferreira. São Paulo: UNESP, 1996.

SAID, Edward. Orientalismo: o Oriente como invenção do Ocidente. Tradução de Tomás Rosa Bueno. SP: Companhia das Letras, 1990, p.13.

SECCO, Carmen Lucia Tindó Ribeiro. Entre sonhos e memórias: trilhas da poesia moçambicana. In: Poesia sempre. Ano 13, número 23, 2006, pp. 229-249.

SECCO, Carmen Lucia Tindó Ribeiro. Antologia do mar na poesia africana de língua portuguesa do século XX - volume II: Moçambique, São Tomé e Príncipe, Guiné-Bissau. Rio de Janeiro: UFRJ, 1999. 
SPINOZA, Benedictus. Ética. Tradução de Tomaz Tadeu. Belo Horizonte: Autêntica, 2009.

SODRÉ, Muniz. As estratégias sensíveis - afeto, mídia e política. Petrópolis: Vozes, 2006.

WHITE, Eduardo. Os materiais do amor seguido de $\mathrm{O}$ desafio da tristeza. Lisboa: Caminho, 1997.

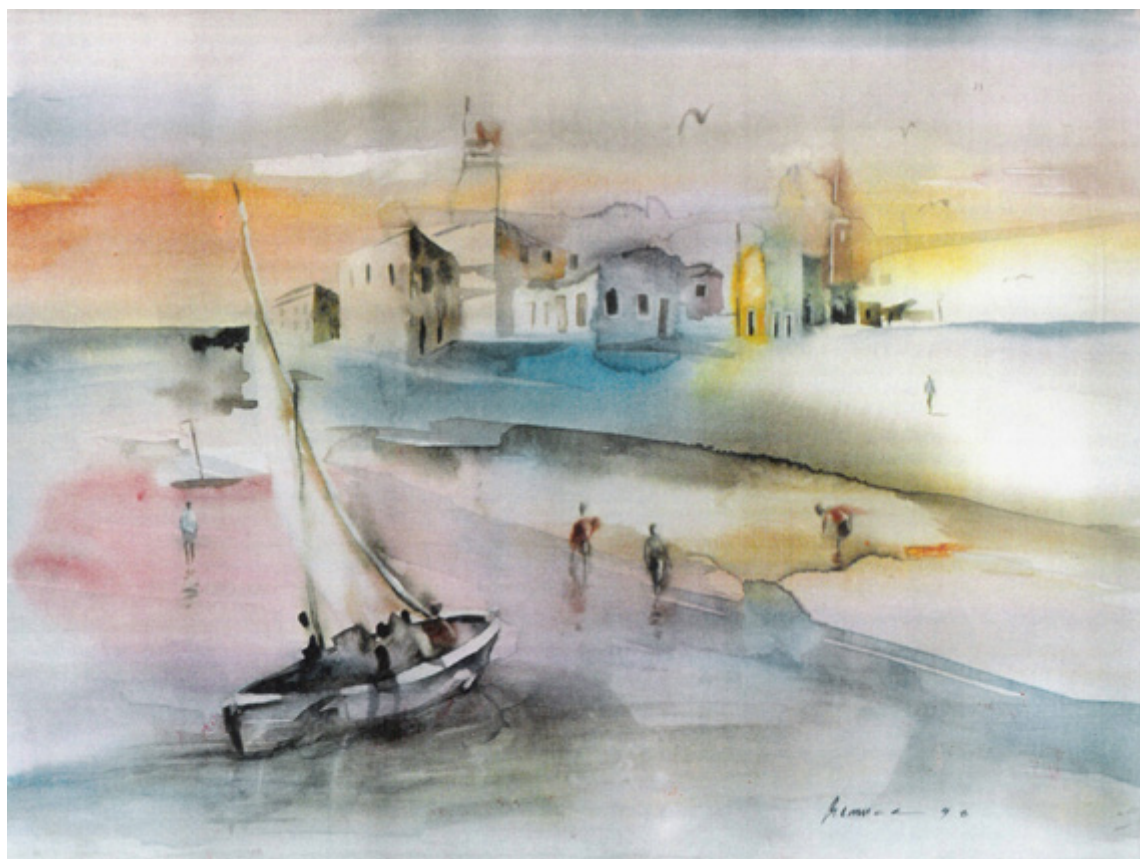

TELA 1 - HILÁRIO GEMUCE - Aguarela da Ilha de Moçambique, sem título, 1995 


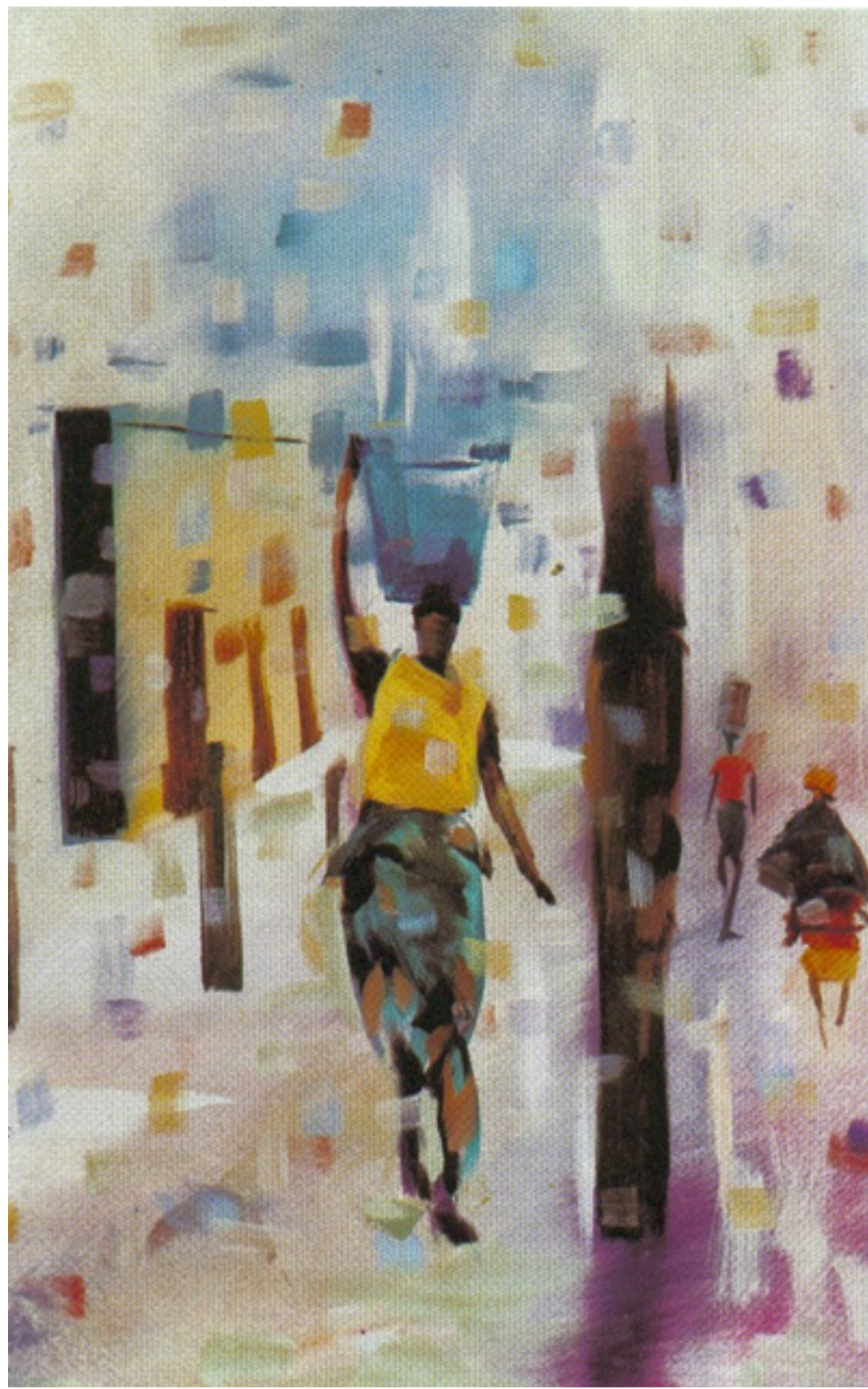



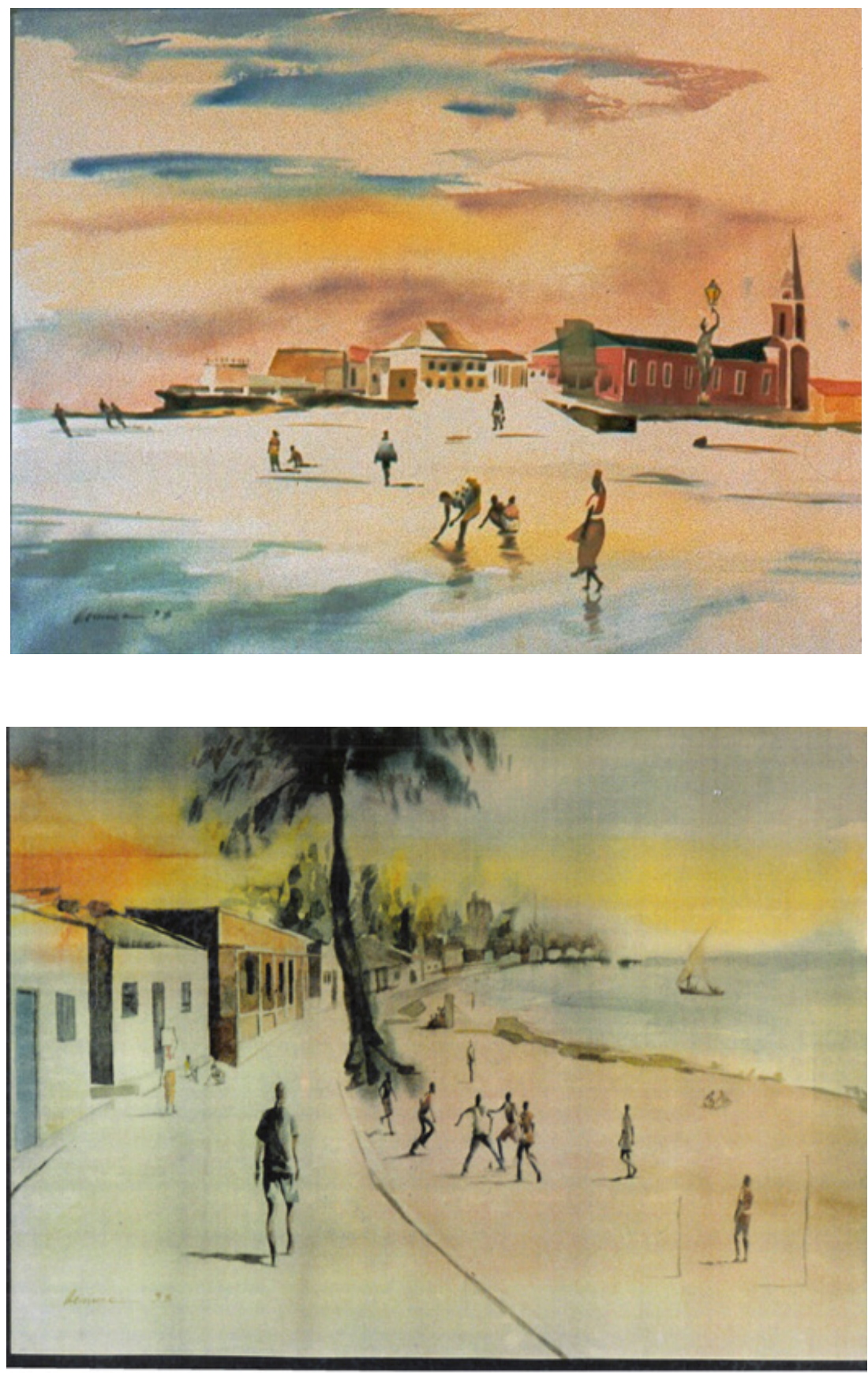


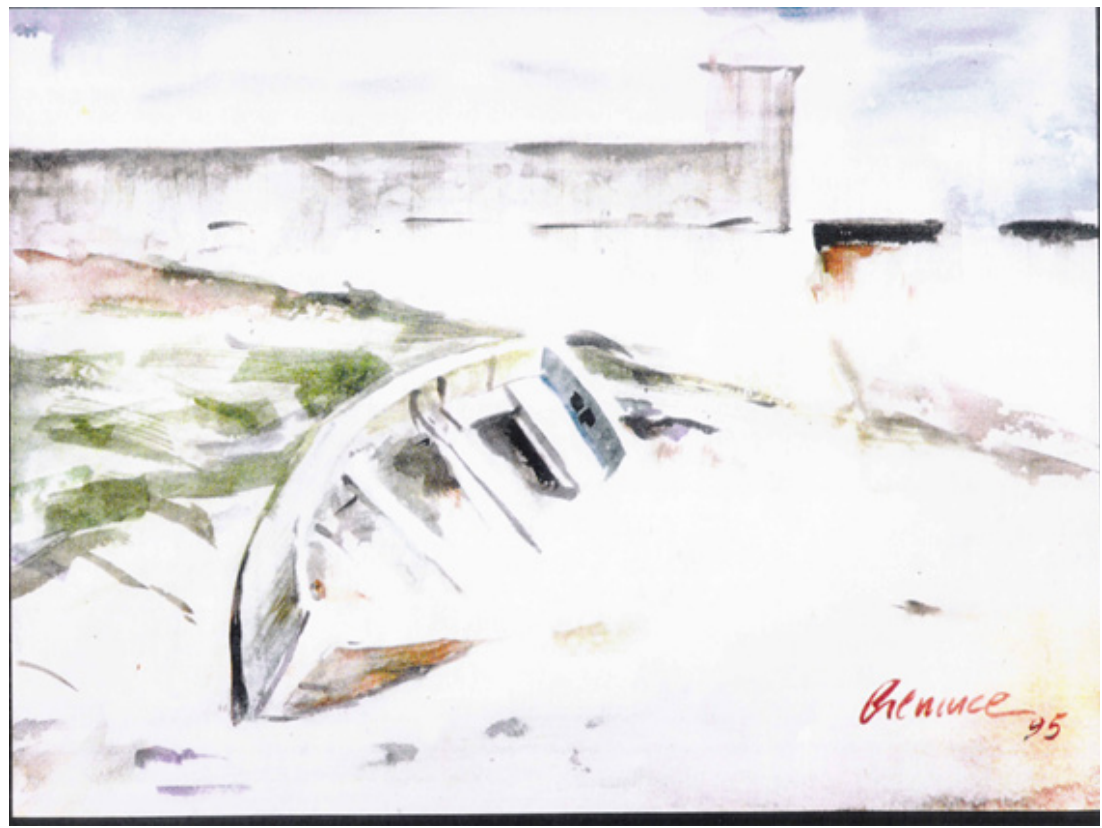

TELA 5 - HILÁRIO GEMUCE - Aguarela. “O barco encalhado”, 1995. 
